\title{
HAK WARIS ANAK LUAR KAWIN YANG LAHIR DARI PERKAWINAN CAMPURAN MENURUT KUH PERDATA DAN UU NO. 1 TAHUN 1974 TENTANG PERKAWINAN
}

\author{
Wijayanto Setiawan ${ }^{1}$
}

\begin{abstract}
Child out of wedlock of intermarriage is a very complicated issue in the light of the law. Some of the problems include: First, concerning the legal status of the child's nationality. Second, the case law of the cases related to private law. Issues of private law, which until now associated with the child's inheritance rights. In view of the legal status of illegitimate children born intermarriage be distinguished: First, illegitimate children born intermarriage whose mother citizen and not recognized by the biological father. Second, illegitimate children born intermarriage whose mother citizen and foreign national father where he was recognized by her biological father. Third, illegitimate children born intermarriage whose mother and father WNA citizens where he was recognized by his father biologisnya.Ketentuan inheritance law to the legal status of illegitimate children born intermarriage are: First, the child out of wedlock of the marriage mix of citizen and his mother was not recognized by her biological father, both Civil Law and Islamic Law holds that the child only has rights to inheritance from his mother and his mother's family and her only applicable law in Indonesia. Second, the illegitimate children born intermarriage whose mother citizen and foreign national father where he was recognized by her biological father. Third, the illegitimate children born intermarriage whose mother and father WNA citizens where he was recognized by her biological father. There are differences between the Civil Code and the Law. 1 of 1974 on Marriage. According to the Civil Code, the child has inheritance rights of both the mother and father and the heir to his father's legal provisions applicable law is the law in the State father's confessor. But according to Law no. 1 of 1974 children only have rights of inheritance from his mother, because the Law no. 1 of 1974 is not known recognition of illegitimate children.
\end{abstract}

Keywords: inheritance rights, child out of wedlock, intermarriage

\begin{abstract}
Abstrak
Anak luar kawin yang lahir dari perkawinan campuran merupakan permasalahan yang sangat pelik dipandang dari sudut hukum. Beberapa permasalahan antara lain adalah: Pertama, menyangkut status hukum kewarganegara si anak. Kedua, pemilihan hukum apabila terjadi kasus-kasus yang terkait dengan hukum privat. Permasalahan hukum privat yang hingga kini berkaitan dengan hak waris si

${ }^{1}$ Penulis adalah Dosen Fakultas Hukum Universitas Hang Tuah Surabaya. Alamat kontak: tt_titik@yahoo.com.
\end{abstract}


anak. Dalam sudut pandang status hukum anak luar kawin yang lahir dari perkawinan campuran dibedakan menjadi: Pertama, anak luar kawin yang lahir dari perkawinan campuran yang ibunya WNI dan tidak diakui oleh ayah biologisnya. Kedua, anak luar kawin yang lahir dari perkawinan campuran yang ibunya WNI dan ayahnya WNA dimana ia diakui oleh ayah biologisnya. Ketiga, anak luar kawin yang lahir dari perkawinan campuran yang ibunya WNA dan ayahnya WNI dimana ia diakui oleh ayah biologisnya.Ketentuan hukum waris terhadap status hukum anak luar kawin yang lahir dari perkawinan campuran tersebut adalah: Pertama, bagi anak luar kawin yang lahir dari perkawinan campuran yang ibunya WNI dan tidak diakui oleh ayah biologisnya, baik hukum Perdata maupun Hukum Islam berpandangan bahwa anak tersebut hanya memiliki hak waris dari ibu dan keluarga ibunya saja dan kepadanya berlaku Hukum Indonesia. Kedua, bagi anak luar kawin yang lahir dari perkawinan campuran yang ibunya WNI dan ayahnya WNA dimana ia diakui oleh ayah biologisnya. Ketiga, bagi anak luar kawin yang lahir dari perkawinan campuran yang ibunya WNA dan ayahnya WNI dimana ia diakui oleh ayah biologisnya. Terdapat perbedaan pandangan antara KUH Perdata dan UU No. 1 Tahun 1974 tentang Perkawinan. Menurut KUH Perdata, si anak memiliki hak waris baik dari ibu maupun ayahnya dan mengenai ketentuan hukum waris terhadap ayahnya hukum yang berlaku adalah hukum di Negara ayah yang mengakuinya. Tetapi menurut UU No. 1 tahun 1974 anak hanya memiliki hak waris dari ibunya saja, karena dalam UU No. 1 tahun 1974 tidak dikenal pengakuan terhadap anak di luar kawin

Kata kunci: hak waris, anak luar kawin, perkawinan campuran

\section{Pendahuluan}

Perkawinan campuran telah merambah seluruh pelosok Tanah Air dan kelas masyarakat. Globalisasi informasi, ekonomi, pendidikan, dan transportasi telah menggugurkan stigma bahwa kawin campur adalah perkawinan antara ekspatriat kaya dan orang Indonesia.

Menurut survey yang dilakukan oleh Mixed Couple Club, jalur perkenalan yang membawa pasangan berbeda kewarga-negaraan menikah antara lain adalah perkenalan melalui internet, kemudian bekas teman kerja/bisnis, berkenalan saat berlibur, bekas teman sekolah/kuliah, dan sahabat pena. Perkawinan campur juga terjadi pada tenaga kerja Indonesia dengan tenaga kerja dari negara. Dengan banyak terjadinya perkawinan campur di Indonesia sudah seharusnya perlindungan hukum dalam perkawinan campuran ini diakomodir dengan baik dalam perundang-undangan di Indonesia.

Dalam perundang-undangan di Indonesia, perkawinan campuran didefinisikan dalam Undang-Undang Nomor 1 Tahun 1974 tentang Perkawinan, Pasal 57:

Yang dimaksud dengan per-kawinan campuran dalam undang-undang ini ialah per-kawinan antara dua orang yang di Indonesia tunduk 


\section{pada hukum yang berlainan, karena perbedaan kewarganegaraan dan salah satu pihak berkewarganegaraan Indonesia.}

Selama hampir setengah abad pengaturan kewarganegaraan dalam perkawinan campuran antara warga negara Indonesia dengan warga negara asing, mengacu pada Undang-Undang Kewarga-negaraan Nomor 62 Tahun 1958. Seiring berjalannya waktu Undang-Undang ini dinilai tidak sanggup lagi mengakomodir kepentingan para pihak dalam perkawinan campuran, terutama perlindungan untuk istri dan anak.

Barulah pada 11 Juli 2006, DPR mengesahkan Undang-Undang Kewarganegaraan yang baru, yaitu Undang-Undang Nomor 12 Tahun 2006. Lahirnya undang-undang ini disambut gembira oleh sekelompok kaum ibu yang menikah dengan warga negara asing, walaupun pro dan kontra masih saja timbul, namun secara garis besar Undang-undang baru yang memperbolehkan dwi kewarga-negaraan terbatas ini sudah memberikan pencerahan baru dalam mengatasi persoalan-persoalan yang lahir dari perkawinan campuran.

Perbedaan pokok antara Undang-Undang Kewarganegaraan Nomor 62 Tahun 1958 dan Undang-Undang kewarga-negaraan Nomor 12 Tahun 2006, adalah bahwa Undang-Undang Kewarganegaraan Nomor 62 Tahun 1958 menganut prinsip kewarganegaraan tunggal, sehingga anak yang lahir dari perkawinan campuran hanya bisa memiliki satu kewarganegaraan, yang dalam Undang-Undang tersebut ditentukan bahwa yang harus diikuti adalah kewarganegaraan ayahnya. Pengatur-an ini menimbulkan persoalan apabila di kemudian hari perkawinan orang tua pecah, tentu ibu akan kesulitan mendapat pengasuhan anaknya yang warga negara asing.

Persoalan lain yang rentan dan sering timbul dalam perkawinan campuran adalah masalah pengaturan hak waris anak. Hal ini berkaitan dengan nasab si anak, apakah yang bersangkutan mengikuti hukum yang berlaku pada ayah ataukah ibunya. Terlebih jika, anak yang lahir dari perkawinan campuran tersebut adalah anak luar kawin.

Dalam konteks hukum yang berlaku di Indonesia, pengaturan mengenai Hukum Waris bagi anak luar kawin diatur dalam ketentuan hukum yang berbedabeda (pluralitas), yaitu Hukum Perdata, khusus-nya bagi bagi warga negara yang non-muslim dan bagi warga muslim berlaku ketentuan Undang-Undang Nomor 1 Tahun 1974 tentang Perkawinan, Inpres No. 1 Tahun 1991 tentang Kompilasi Hukum Islam selain berlaku Hukum Islam sendiri.

Menurut ketentuan Hukum Perdata kedudukan ahli waris anak luar kawin selama diakui oleh orang tuanya tidak menimbulkan per-masalahan yang berarti artinya, si anak tetap memperoleh hak waris dari kedua orang tuanya meskipun berbeda dengan kedudukan waris bagi anak syah. Tetapi hal ini berbeda dengan ketentuan yang ada dalam Undang-Undang Nomor 1 Tahun 1974 tentang Perkawinan, Instruksi Presiden (Inpres) Nomor 1 Tahun 1991 tentang Kompilasi Hukum Islam dan Hukum Islam. Menurut ketiga aturan tersebut, bahwa anak luar kawin hanya memiliki hubungan hukum dengan ibu dan keluarga ibunya, dan tidak memiliki hubungan hukum dengan ayah zinanya. 
Perbedaaan pengaturan mengenai kedudukan ahli waris anak luar kawin yang lahir dari perkawinan campuran ini sangat menarik untuk dikaji, terutama berkaitan dengan aturan hukum mana yang harus dipilih bagi yang berkepentingan (anak luar kawin) ketika ia harus menggunakan haknya selaku warga negara dan warga masyarakat hukum.

Berdasarkan permasalahan tersebut, secara garis besar perumusan masalah adalah sebagai berikut:

1. Bagaimana status hukum (nasab) anak luar kawin yang lahir dari perkawinan campuran?

2. Bagaimana Kedudukan Hak Waris bagi anak luar kawin yang lahir dari perkawinan campuran?

\section{Status Hukum Anak Luar Kawin yang Lahir dari Perkawinan Campuran}

\section{Status Hukum Anak Luar Kawin}

Definisi anak menurut Pasal 1 Angka 1 Undang-Undang Nomor 23 Tahun 2002 tentang Perlindungan Anak adalah:

Anak adalah seseorang yang belum berusia 18 (delapan belas)

tahun, termasuk anak yang masih dalam kandungan.

Dalam hukum perdata, diketahui bahwa manusia memiliki status sebagai subjek hukum sejak ia dilahirkan. Pasal 2 KUHP memberi pengecualian, bahwa anak yang masih dalam kandungan dapat menjadi subjek hukum apabila ada kepenting-an yang menghendaki dan dilahirkan dalam keadaan hidup.

Keberadaan anak dalam keluarga merupakan sesuatu yang sangat berarti. Anak memiliki arti yang berbeda-beda bagi setiap orang. Anak merupakan penyambung keturunan, sebagai investasi masa depan, dan anak merupakan harapan untuk menjadi sandaran di kala usia lanjut. Ia dianggap sebagai modal untuk meninggkatkan peringkat hidup sehingga dapat mengontrol status sosial orang tua. Anak merupakan pemegang keistimewaan orang tua, waktu orang tua masih hidup, anak sebagai penenang dan sewaktu orang tua telah meninggal, anak adalah lambang penerus dan lambang keabadian. Anak mewarisi tanda-tanda kesamaan dengan orang tuanya, termasuk ciri khas, baik maupun buruk, tinggi, maupun rendah. Anak adalah belahan jiwa dan potongan daging orang tuanya. $^{2}$

Begitu pentingnya eksistensi anak dalam kehidupan manusia, maka Allah SWT mensyari'atkan adanya perkawinan. Pensyari'atan perkawinan memiliki tujuan antara lain untuk berketurunan (memiliki anak) yang baik,

\footnotetext{
2 Yusuf al-Qadhawi, "Halal dan Haram dalam Islam", (Surabaya: Bina Ilmu, 1976), hal. 256-258.
} 
memelihara nasab, menghindarkan diri dari penyakit dan menciptakan keluarga yang sakinah. ${ }^{3}$ Oleh karena itu agama Islam melarang perzinaan. Hukum Islam memberi sanksi yang berat terhadap perbuatan zina. Karena zina dapat mengakibatkan ketidakjelasan ke-turunan. Sehingga ketika lahir anak sebagai akibat dari perbuatan zina, maka akan ada keraguan tentang siapa bapaknya. Dengan adanya perkawinan setiap anak yang lahir dari tempat tidur suami, mutlak menjadi anak dari suami itu, tanpa memerlukan peng-akuan darinya. ${ }^{4}$

Pergaulan bebas antara muda-mudi yang banyak terjadi sekarang ini, seringkali membawa kepada hal-hal yang negatif yang tidak di-kehendaki, seperti hubungan seks luar nikah dan hamil luar nikah. Hal ini disebabkan oleh adanya pergesekan budaya, sehingga pada saat ini menggejala dimasyarakat adanya hidup bersama antara seorang pria dan wanita tanpa adanya ikatan perkawinan.

Anak yang lahir di luar nikah mendapatkan julukan dalam masyarakat sebagai anak haram, hal ini menimbulkan gangguan psikologis bagi anak, walaupun secara hokum anak tersebut tidak mempunyai akibat hukum dari perbuatan orang tuanya, namun banyak persoalan yang muncul akibat hamil luar nikah tersebut, seperti hubungan nasab antara anak dengan bapak biologisnya, dan lain sebagainya dari berbagai perspektif hukum.

\section{a. Pengaturan Menurut Hukum Perdata Internasional}

Menurut teori hukum perdata internasional, untuk menentukan status anak dan hubungan antara anak dan orang tua, perlu dilihat dahulu perkawinan orang tuanya sebagai persoalan pendahuluan, apakah perkawinan orang tuanya sah sehingga anak memiliki hubungan hukum dengan ayahnya, atau perkawinan tersebut tidak sah, sehingga anak dianggap sebagai anak luar nikah yang hanya memiliki hubungan hukum dengan ibunya.

Sejak dahulu diakui bahwa soal keturunan termasuk status personal. Negara-negara common law berpegang pada prinsip domisili (ius soli) sedangkan negara-negara civil law berpegang pada prinsip nasionalitas (ius sanguinis). Umumnya yang dipakai ialah hukum personal dari sang ayah sebagai kepala keluarga (pater familias) pada masalah-masalah keturunan secara sah. Hal ini adalah demi kesatuan hukum dalam keluarga dan demi kepentingan kekeluarga-an, demi stabilitas dan kehormatan dari seorang istri dan hak-hak maritalnya. Sistem kewarganegaraan dari ayah adalah yang terbanyak dipergunakan di negara-negara lain, seperti misalnya Jerman, Yunani, Italia, Swiss dan kelompok negara-negara sosialis.

${ }^{3}$ Wahbah al-Zuhailiy, "Al-Fiqh al-Islamiy wa Adillatuhu:, (Beirut: Dar al-Fikr. 1997), hal.

${ }^{4}$ Op. Cit., hal. 304-306. 
Dalam sistem hukum Indonesia, Sudargo Gautama menyatakan kecondongannya pada sistem hukum dari ayah demi kesatuan hukum dalam keluarga, bahwa semua anak-anak dalam keluarga itu sepanjang mengenai kekuasaan tertentu orang tua terhadap anak mereka (ouderlijke macht) tunduk pada hukum yang sama. Kecondongan ini sesuai dengan prinsip dalam UU Kewarganegaraan No. 62 tahun 1958.

Kecondongan pada sistem hukum ayah demi kesatuan hukum, memiliki tujuan yang baik yaitu kesatuan dalam keluarga, namun dalam hal kewarganegaraan ibu berbeda dari ayah, lalu terjadi perpecahan dalam perkawinan ter-sebut maka akan sulit bagi ibu untuk mengasuh dan membesarkan anak-anaknya yang berbeda kewarga-negaraan, terutama bila anak-anak tersebut masih dibawah umur.

\section{b. Pengaturan Menurut Hukum Nasional}

Pengaturan hukum bagi anak luar kawin dalam Hukum Nasional di kelompokkan apakah keluarga tersebut muslim atau non-muslim. Bagi keluarga non muslim berlaku hukum perdata barat (BW), sedangkan bagi keluarga muslim berlaku dua aturan hukum: Pertama, berdasarkan Undang-Undang Nomor 1 Tahun 1974 tentang Perkawinan; dan Kedua, Instruksi Presiden Nomor 1 Tahun 1991 tentang Kompilasi Hukum Islam.

\section{1) Pengaturan Menurut Hukum Perdata Barat (BW)}

Menurut Hukum Perdata (BW), bahwa sanak keluarga sedarah yang tidak sah hanya bertindak sebagai anak keluarga dalam hukum waris sepanjang ada hubung-an perdata antara mereka dengan sanak keluarga.

Seorang ibu tidak dapat melahir-kan anak yang tidak sah, maka dengan kelahiran saja sudah menjadi hubung-an perdata antara ibu dengan anak. Antara ayah dengan anak hubungan ini hanyalah terjadi oleh pengakuan.

Anak yang tidak sah, yang hubungan perdata dengan satu orang tuanya, dinamakan anak luar nikah dari orang tua itu. Dengan kelahirannya, maka anak yang tidak sah itu menjadi anak luar nikah dari si ibu. Dengan pengakuan si ayah ia menjadi anak luar nikah dari si ayah. Antara anak luar nikah dengan sanak keluarga sedarah dari orang tuanya, pada asas-nya tidak timbul hubungan perdata.

Seorang anak luar nikah tidak akan pernah dapat mewarisi dari sanak keluarga orang tuanya, dan sebaliknya sanak keluarga tidak dapat bertindak dalam harta peninggalan anak luar nikah dari salah seorang anggota keluarganya.

Pasal 873 KUHPerdata walaupun dalam hal yang jarang terjadi memungkinkan terjadinya peristiwa yang demikian itu. Seorang anak luar nikah karena tidak ada hubungan perdata antara dia dengan sanak keluarga dari orang tuanya, maka untuk sebagian 
besar berada diluar ikatan keluarga. Tetapi terhadap si ibu dan si ayah anak luar nikah itu mempunyai kedudukan yang terkebelakang dibandingkan dengan anak yang sah. ${ }^{5}$

Pendapat masyarakat dan paham kesusilaan untuk sebagian besar tercermin dalam kedudukan hukum dari anak yang tidak sah. Dijaman dimana orang mengang-gap kekuatan ikatan keluarga tiang penyangga yang paling penting untuk tata tertib masyarakat, maka kedudukan hukum anak luar nikah itu tidaklah begitu baik.

Pembuat UU mengorbankan kepentingan anak luar nikah demi kepentingan masyarakat yang lebih besar yang tersangkut pada kemurnian ikatan keluarga.

Dalam sejarah ada waktunya dimana pertimbangan atas dasar sifat manusia yang sejati, membuat keadaan lebih menguntung-kan anak luar nikah.

Sistim Code Civil memberikan kepada anak yang diakui sebagian dari harta peninggalan orang tuanya: tetapi mereka sepertinya tidak bertindak sebagai ahli waris, tetapi sebagai kreditur, karena mereka termasuk waris luar biasa.

Dalam harta peninggalan sanak ke-luarga dari orang tuanya anak yang diakui hanyalah mempunyai hak, apabila tidak ada seorang sanak keluarga sedarah dari yang meninggal.

Pembuat UU kita untuk sebagian besar meniru sistem Code Civil. Bedanya ialah bahwa dalam perundang-undangan kita anak luar nikah bertindak sebagai ahli waris, karena itu mereka mempunyai hak untuk menuntut berdasarkan Pasal 834 KUHPerdata. Dari perkataan me-nuntut dalam Pasal 834 ternyata, bahwa pembuat UU kita memberikan tempat pada anak luar nikah sebagai ahli waris.

Menurut BW ada kemungkinan seorang anak tidak hanya tidak mempunyai bapak, melainkan juga tidak mempunyai ibu dalam arti, bahwa antara anak seorang perempuan yang melahirkan itu, tiada perhubungan hukum sama sekali mengenai pemberian nafkah warisan dan lain-lain. ${ }^{6}$

Antara anak yang tidak sah dengan sanak keluarga sedarah dari orang tuanya, hanyalah ada hubungan perdata apabila antara anak yang tidak sah itu dengan orang tua ada hubungan perdata, jadi dipihak ibu selalu ada hubungan perdata dan dipihak ayah hanya akan ada apabila si ayah mengakui.

Undang-undang membicarakan dalam bagian ketiga, hukum waris aktif dan pasif dari anak luar nikah, artinya perolehan dari anak luar nikah.

\footnotetext{
${ }^{5}$ A. Pitlo, "Hukum Waris Menurut KUHPerdata", (Jakarta: Intermasa. 1979), hal. 51.

${ }^{6}$ Wirjono Prodjodikoro, "Hukum Warisan di Indonesia", (Bandung: Sumur, 1974), hal. 50.
} 
Untuk hukum waris aktif dari anak luar nikah tidak ada bedanya apakah pengakuan oleh si ayah terjadi sebelum atau sesudah matinya anak luar nikah. Tentang hukum waris pasif dari anak luar nikah lain lagi duduk soalnya. Pengakuan sesudah mati tidak menimbulkan hak waris dalam harta peninggalan anak luar nikah. Undang-undang tidak membicarakan hal itu.

Hanyalah akal sehat dan per-timbangan kepatutanlah yang menjadi alasan bagi pendapat ini. Antara anak yang tidak diakui oleh ayahnya dan sanak keluarga ayah tidak satupun hubungan hukum keluarga, oleh sebab itu dalam hal ini tidak ada hukum waris. Sepanjang tidak ada hubungan perdata, atau karena hukum (si ibu) atau karena pengakuan (si ayah), maka hubungan keluarga yang tidak sah itu tidak berarti apa-apa dalam hukum waris.

Karena kelahiran itu sendirilah ada hubungan antara ibu dan anak. Hubungan anak dan laki-laki yang membuahkannya tidak ada. Jadi barulah karena pengakuannya lahirlah hubungan hukum antara anak dan laki-laki yang mengakuinya. Walaupun demikian kedudukannya tetap terkebelakang dibandingkan dengan anak sah, terutama dalam hukum waris. Selain itu anak luar nikah baik yang diakui maupun tidak berada dibawah kekuasaan orang tua melainkan di bawah perwalian.

Mengenai arti pengakuan itu sendiri tidak ada kesatuan pendapat. Apakah pe-ngakuan itu adalah bukti adanya hubungan kekeluargaan yang alamiah? Ataukah pengakuan itu adalah suatu perbuatan hukum yang menimbulkan hubungan kekeluarga-an sehingga bukan keturunanlah melainkan pengakuannya itu yang menjadi sumber hubungan hukum antara orang tua dan anaknya?

Bagaimanakah dengan pengaku-an yang bertentangan dengan kebenar-an? Apakah itu merupakan pemalsuan dalam surat itu suatu perbuatan hukum maka pengakuan yang bertentangan dengan kebenaran itu boleh dan karena itu tidak dapat dituntut pemalsuan atau penggelapan kenyata-an.

Kalau pengakuan itu dianggap suatu perbuatan hukum, yang ber-dasarkan fakta bahwa yang mengakui itu adalah orang tua dari anak itu.

Karena pengakuan itu bukanlah upaya bukti maka ada kemungkinan pengakuan itu dibatalkan oleh peng-adilan. Karena dasar pengakuan itu adalah fiksi bahwa yang diakui itu adalah anaknya maka tidak mungkin bahwa yang mengakui itu lebih muda dari yang diakuinya.

\section{2) Pengaturan Menurut Undang-Undang Nomor 1 Tahun 1974 tentang Perkawinan dan Inpres Nomor 1 Tahun 1991 tentang Kompilasi Hukum Islam (KHI)}

Menurut Hukum Perkawinan Nasional Indonesia, status anak dibedakan menjadi dua: pertama, anak sah. kedua, anak luar nikah. 
Anak sah sebagaimana yang dinyatakan Undang-Undang Nomor 1 Tahun 1974 tentang Perkawinan Pasal 42: adalah dalam anak yang dilahirkan dalam atau sebagai akibat perkawinan yang sah. Dan Kompilasi Hukum Islam (KHI) Pasal 99 yang menyatakan: "anak sah adalah: (a) anak yang lahir dalam atau sebagai akibat perkawinan yang sah; (b). Hasil pembuahan suami istri yang sah di luar rahim dan dilahirkan oleh istri tersebut. ${ }^{7}$

Bila dicermati secara analisis, seperti-nya bunyi pasal tentang anak sah ini memimbulkan kerancuan, anak sah adalah anak yang lahir dalam atau sebagai akibat perkawinan yang sah. Bila dinyatakan "anak yang lahir akibat perkawinan yang sah" tidak ada masalah, namun "anak yang lahir dalam masa perkawinan yang sah" ini akan memimbulkan suatu kecurigaan bila pasal ini dihubungkan dengan pasal yang membolehkan wanita hamil karenan zina, menikah dengan pria yang menghamilinya. Perkawinan perempuan hamil karena zina dengan laki laki yang menghamilinya adalah perkawinan yang sah. Seandainya beberapa bulan sesudah perkawinan yang sah itu berlansung, lahir anak yang dikandungnya, tentu akan berarti anak yang lahir anak sah dari suami yang mengawininya bila masa kelahir-an telah enam bulan dari waktu pernikahan.

Yang dimaksud dengan anak luar nikah adalah anak yang dibuahi dan dilahirkan di luar pernikahan yang sah, sebagaimana yang disebutkan dalam peraturan perundang-undangan Nasional antara lain:

(1) UU No. 1 Tahun 1974 Pasal 43 ayat 1, menyatakan anak yang dilahirkan di luar perkawinan hanya mempunyai hubungan perdata dengan ibunya dan keluarga ibunya;

(2) Kompilasi Hukum Islam (KHI) pasal 100, menyebutkan anak yang lahir diluar perkawinan hanya mempunyai hubungan nasab dengan ibunya dan keluarga ibunya.

Pada akhirnya bila dicermati dari peraturan perundangundangan yang berlaku di Indonesia tentang Hukum Perkawinan, menyatakan bahwa status nasab anak di luar nikah mempunyai hubungan keperdata-an hanya kepada ibunya dan keluarga ibunya. Hubung-an ini biasa disebut dengan kekuasaan orang tua, yakni timbulnya hak dan kewajiban antara orang tua dan anak. Implementasinya adalah bahwa anak di luar nikah hanya memiliki hubung-an yang menimbulkan adanya anak dan kewajiban dengan ibu dan kelaurga ibunya. Agaknya dapat di-nyatakan mafhum mukhalafah dari pernyataan tersebut bahwa anak itu tidak mempunyai hubungan ke-perdataan dengan bapak biologisnya dalam bentuk; nasab; hak dan kewajiban secara timbal balik. Secara

\footnotetext{
${ }^{7}$ Abdurrahman, "Kompilasi Hukum Islam", (Jakarta: Akademika Presindo, 1995), hal. 60.
} 
implisit dapat ditegaskan bahwa hampir tidak ada perbedaan antara hukum Islam dengan hukum per-kawinan Nasional dalam menetapkan nasab anak di luar nikah, walaupun tidak dinyatakan secara tegas hubungannya dengan bapak biologis, dalam pasal tertentu.

Berbeda dengan pengaturan anak yang ada dalam UU No. 1 Tahun 1974, jika diteliti secara mendalam, Kompilasi Hukum Islam tidak menentukan secara khusus dan pasti tentang pengelompokan jenis anak, sebagaimana pengelompokan yang terdapat dalam hukum perdata umum. Dalam Kompilasi Hukum Islam selain dijelaskan tentang kriteria anak sah (yang dilahirkan dalam ikatan perkawinan yang sah), sebagaimana yang dicantumkan dalam Pasal 99 Kompilasi Hukum Islam, yang berbunyi bahwa anak yang sah adalah:

(1) Anak yang dilahirkan dalam atau akibat perkawinan yang sah;

(2) Hasil pembuahan suami isteri yang di luar rahim dan dilahirkan oleh isteri tersebut.

Juga dikenal anak yang lahir di luar perkawinan yang sah, seperti yang tercantum dalam Pasal 100 Kompilasi Hukum Islam bahwa "anak yang lahir di luar perkawinan hanya mempunyai hubungan nasab dengan ibunya dan keluarga ibunya".

Di samping itu dijelaskan juga tentang status anak dari perkawinan seorang laki-laki dengan perempuan yang dihamilinya sebelum pernikahan. Sebagaimana yang tercantum pada Pasal 53 ayat (3) Kompilasi Hukum Islam:

Dengan dilangsungkannya perkawinan pada saat wanita hamil, tidak diperlukan perkawinan setelah anak yang dikandung lahir.

Begitu juga dalam Pasal 75 huruf (b) Kompilasi Hukum Islam juga dijelaskan tentang status anak dari perkawinan yang dibatalkan, yang berbunyi:

Keputusan pembatalan perkawinan tidak berlaku surut terhadap anak-anak yang dilahirkan dari perkawinan tersebut.

Sedangkan dalam Pasal 162 Kompilasi Hukum Islam dijelaskan tentang status anak $l i$ 'an (sebagai akibat peng-ingkaran suami terhadap janin dan/atau anak yang dilahirkan isterinya).

Dengan demikian, jelas bahwa Kompilasi Hukum Islam tidak ada me-ngelompokkan pembagian anak secara sistematis yang disusun dalam satu Bab tertentu, sebagaimana pengklasifikasian yang tercantum dalam UU Nomor 1 Tahun 1974. Dalam pasal 42 Bab IX UU Nomor 1 Tahun 1974 tersebut dijelaskan bahwa anak yang sah adalah anak yang dilahirkan dan atau sebagai akibat 
perkawinan yang sah. Yang termasuk dalam kategori pasal ini adalah:

(1) Anak yang dilahirkan oleh wanita akibat suatu ikatan perkawinan yang sah;

(2) Anak yang dilahirkan oleh wanita di dalam ikatan perkawainan dengan tenggang waktu minimal 6 (enam) bulan antara peristiwa pernikahan dengan melahirkan bayi;

(3) Anak yang dilahirkan oleh wanita dalam ikatan perkawinan yang waktunya kurang dari kebiasaan masa kehamilan tetapi tidak diingkari kelahirannya oleh suami.

Karena itu untuk mendekatkan pengertian "anak di luar nikah" akan diuraikan pendekatan berdasarkan ter-minology yang tertera dalam kitab fikih, yang dipadukan dengan ketentuan yang mengatur tentang status anak yang tertera dalam pasal-pasal UU Nomor 1 Tahun 1974 dan Kompilasi Hukum Islam.

Hasanayn Muhammad Makluf membuat terminology anak zina sebagai anak yang dilahirkan sebagai akibat dari hubung-an suami isteri yang tidak sah.

Hubungan suami isteri yang tidak sah sebagaimana dimaksud adalah hubungan badan (senggama atau wathi') antara dua orang yang tidak terikat tali pernikahan yang memenuhi unsur rukun dan syarat nikah yang telah ditentukan.

Selain itu, hubungan suami isteri yang tidak sah tersebut, dapat terjadi atas dasar suka sama suka ataupun karena perkosaan, baik yang dilakukan oleh orang yang telah menikah ataupun belum menikah. Meskipun istilah "anak zina" merupa-kan istilah yang popular dan melekat dalam kehidupan masyarakat, namun Kompilasi Hukum Islam tidak mengadopsi istilah tersebut untuk dijadikan sebagai istilah khusus di dalamnya.

Hal tersebut bertujuan agar "anak" sebagai hasil hubungan zina, tidak dijadikan sasaran hukuman sosial, celaan masyarakat dan lain sebagainya, dengan menyandang-kan dosa besar (berzina) ibu kandungnya dan ayah alami (genetik) anak tersebut kepada dirinya, sekaligus untuk menunjuk-an identitas Islam tidak mengenal adanya dosa warisan. Untuk lebih mendekatkan makna yang demikian, Pasal 44 ayat (1) UU Nomor 1 Tahun 1974 hanya menyatakan "seorang suami dapat menyengkal sahnya anak yang dilahirkan oleh isterinya, bilamana ia dapat membuktikan bahwa isterinya telah berzina dan kelahiran anak itu akibat daripada perzinaan tersebut.

Dalam Kompilasi Hukum Islam kalimat yang mempunyi makna "anak zina" sebagaimana definisi yang dikemukaan oleh Hasanayn di atas, adalah istilah "anak yang dilahirkan di luar perkawinan yang sah", sebagaimana yang terdapat pada Pasal 100 Kompilasi Hukum Islam, yang menyebutkan, bahwa: 
Anak yang lahir di luar perkawinan hanya mempunyai hubungan nasab dengan ibunya dan keluarga ibunya.

Semakna dengan ketentuan tersebut, Pasal 186 Kompilasi Hukum Islam menyatakan:

Anak yang lahir di luar perkawinan hanya mempunyai hubungan saling mewarisi dengan ibunya dan keluarga dari pihak ibunya.

Berdasarkan defenisi dan pendekatan makna "anak zina" di atas, maka yang dimaksudkan dengan anak zina dalam pembahasan ini adalah anak yang janin/pembuahannya me-rupakan akibat dari perbuatan zina, ataupun anak yang dilahirkan di luar perkawinan, sebagai akibat dari perbuatan zina.

Pendekatan istilah "anak zina" sebagai "anak yang lahir di luar perkawinan yang sah", berbeda dengan pengertian anak zina yang dikenal dalam hukum perdata umum, sebab dalam perdata umum, istilah anak zina adalah anak yang dilahirkan dari hubungan dua orang, laki-laki dan perempuan yang bukan suami isteri, di mana salah seorang atau kedua-duanya terikat satu perkawinan dengan orang lain. Karena itu anak luar nikah yang dimaksud dalam hukum perdata adalah anak yang dibenih-kan dan dilahirkan di luar perkawinan dan istilah lain yang tidak diartikan sebagai anak zina.

Perbedaan anak zina dengan anak luar kawin menurut hukum perdata adalah:

(1) Apabila orang tua salah satu atau keduannya masih terikat dengan perkawinan lain, kemudian mereka melakukan hubungan seksual dan melahirkan anak, maka anak tersebut disebut anak zina;

(2) Apabila orang tua anak di luar kawin itu masih sama-sama bujang (jejaka, perawan, duda dan janda), mereka mengadakan hubungan seksual dan melahir-kan anak maka anak itu disebut anak luar kawin.

Dengan demikian sejalan dengan Pasal 43 ayat (1) UU Nomor 1 Tahun 1974 yang rumusannya sama dengan Pasal 100 KHI, adalah:

Anak yang lahir di luar perkawinan hanya mempunyai hubungan nasab dengan ibunya dan keluarga ibunya.

Yang termasuk anak yang lahir di luar pernikahan adalah:

(1) Anak yang dilahirkan oleh wanita yang tidak mempunyai ikatan perkawinan yang sah dengan pria yang menghamilinya.

(2) Anak Yang dilahirkan oleh wanita akibat korban perkosaan oleh satu orang pria atau lebih;

(3) Anak yang dilahirkan oleh wanita yang di li'an (diingkari) oleh suaminya; 
(4) Anak yang dilahirkan oleh wanita yang kehamilannya akibat salah orang (salah sangka), disangka suami ternyata bukan;

(5) Anak yang dilahirkan oleh wanita yang kehamilannya akibat pernikahan yang diharam-kan seperti menikah dengan saudara kandung atau saudara sepesusuan.

Angka 4 dan 5 di atas dalam hukum Islam disebut anak subhat yang apabila diakui oleh Bapak subhatnya, nasabnya dapat dihubung-kan kepadanya.

\section{Status Hukum Anak Luar Kawin Yang Lahir dari Perkawinan Campuran}

Seperti telah dibahas pada bagian ter-dahulu, bahwa berdasarkan ketentuan Hukum Islam maupun Hukum Nasional Indonesia kecuali Hukum Perdata (BW) dalam hal ada pengakuan dari sang ayah, bahwa anak yang lahir di luar perkawinan hanya mempunyai hubungan perdata dengan ibunya dan keluarga ibunya. Hal ini dipertegas dalam Pasal 43 ayat (1) UndangUndang Perkawinan Nomor 1 Tahun 1974 jo Pasal 186 Kompilasi Hukum Islam dijelaskan bahwa "Anak yang dilahirkan di luar perkawinan hanya mempunyai hubungan perdata dengan ibunya dan keluarga ibunya".

Yang menjadi pertanyaan adalah hukum mana yang harus diikuti senadainya anak luar kawin tersebut merupakan anak yang lahir dari perkawinan campuran? Dalam perundang-undangan di Indonesia, perkawinan campuran didefinisikan dalam Undang-undang No. 1 Tahun 1974 tentang Perkawinan, Pasal 57:

Yang dimaksud dengan per-kawinan campuran dalam undangundang ini ialah perkawinan antara dua orang yang di Indonesia tunduk pada hukum yang berlainan, karena perbedaan kewarganegaraan dan salah satu pihak berkewarganegaraan Indonesia.

Berdasarkan ketentuan tersebut, maka apabila sang Ibu berkewarganegaraan Indonesia, maka si Anak akan mengikuti warga negara dan hukum sang Ibu. Bila sang Ibu berkewarganegaraan asing maka si Anak akan ikut warga negara ibunya yang WNA.

Kedudukan anak (status hukum kewarganegaraan) diatur dalam Undang-Undang Nomor 12 Tahun 2006 (UU 12/2006) tentang Kewarganegaraan. Berdasarkan Pasal 4 huruf c dan d UU Kewarganegaraan anak yang lahir dari perkawinan seorang wanita WNI dengan pria WNA, maupun anak yang lahir dari perkawinan seorang wanita WNA dengan pria WNI, sama-sama diakui sebagai warga negara Indonesia. Anak tersebut akan berkewarganegaraan ganda, dan setelah anak berusia 18 tahun atau sudah kawin maka ia harus menentukan pilihannya (Pasal 6 ayat (1) UU Kewarganegaraan RI yang baru). Pernyataan untuk memilih tersebut harus disampaikan paling lambat 3 (tiga) tahun setelah anak berusia 18 tahun atau setelah kawin (Pasal 6 ayat (3) UU Kewarganegaraan RI yang baru). 
Permasalahannya adalah bagaimana jika status anak tersebut adalah anak di luar perkawinan? Kedudukan hukum kewarganegaraan anak di luar perkawinan yang lahir dari perkawinan campuran diatur Pasal 4 huruf g. Pasal ini mengatur mengenai siapakah yang bisa disebut sebagai warga negara Indonesia, yaitu:

Anak yang lahir di luar perkawinan yang sah dari seorang ibu Warga Negara Indonesia.

Bersarkan ketentuan di atas, maka anak yang lagir diluar perkawinan yang sah dari ibu yang berkewarganegaraan Indonesia, maka anak tersebut adalah warga negara Indonesia. Jadi hukum yang berlaku baginya adalah hukum Indonesia.

Lalu bagaimana dengan anak luar kawin yang ibunya WNA dan ayahnya WNI, tetapi sang ayah mau mengakui Anak tersebut sebagai Anaknya? UU 12/2006 juga telah mengatur mengenai hal tersebut, di mana dalam Pasal 4 huruf h tercantum bahwa WNI adalah:

Anak yang lahir di luar perkawinan yang sah dari seorang ibu warga negara asing yang diakui oleh seorang ayah Warga Negara Indonesia sebagai anaknya dan pengakuan itu dilakukan sebelum anak tersebut berusia 18 (delapan belas) tahun atau belum kawin.

Ketentuan di atas memberikan implikasi, bahwa anak luar perkawinan yang ibunya WNA dan ayahnya WNI sedangkan ayahnya sendiri mau mengakui, maka sebelum berusia 18 tahun anak tersebut berkewarganegraan ganda (WNI dan WNA), hadi baginya berlaku dua ketentuan sistem hukum. Tetapi setelah mereka berusia 18 tahun - mereka harus memilih kewarganegaraan apakah mengikuti kewarga-negraan ibunya (WNA) atau ayahnya (WNI).

Kemudian bagaimana dengan anak luar nikah yang ibunya WNI lalu ayahnya WNA tapi sang ayah mau mengakui anak tersebut? Berdasarkan Pasal 5 (1) UU 12/2006, dijelaskan:

Anak Warga Negara Indonesia yang lahir di luar perkawinan yang sah, belum berusia 18 (delapan belas) tahun atau belum kawin diakui secara sah oleh ayahnya yang berkewarga-negaraan asing tetap diakui sebagai Warga Negara Indonesia.

Tetap diakuinya anak-anak tersebut diatas sebagai WNI berdasarkan Pasal 6 UU 12/2006 menyebabkan anak-anak ini mem-punyai kewarganegaraan ganda sampai usianya 18 tahun atau sudah kawin, di mana ia dibolehkan untuk memilih kewarganegaraannya. Pernyataan untuk memilih kewarga-negaraan disampaikan secara tertulis kepada Pejabat yang ditugaskan oleh menteri untuk mengurusi bidang kewarga-negaraan, dengan dilampiri dokumen sesuai peraturan perundangan.

Anak-anak yang lahir dari hubungan luar kawin lalu diakui atau diakui secara sah oleh ayahnya yang WNA atau WNI, seperti tersebut diatas, dan ia belum berusia 18 (delapan belas) tahun atau belum kawin memperoleh 
Kewarganegaraan Republik Indonesia berdasarkan Undang-Undang 12/2006 dengan mendaftarkan diri kepada Menteri melalui Pejabat atau Perwakilan Republik Indonesia paling lambat 4 (empat) tahun setelah Undang-Undang ini diundangkan.

\section{Hak Waris bagi Anak Luar Kawin yang Lahir dari Perkawinan Campuran}

\section{Hak Waris Bagi Anak Luar Kawin}

\section{a. Hak Waris Bagi Anak Luar Kawin Menurut KUH Perdata (BW)}

Menurut KUH Perdata terdapat 3 [tiga] golongan anak sebagai keturunan, yaitu:

1) Anak sah;

2) Anak di luar perkawinan yang diakui;

3) Anak di luar perkawinan yang tidak diakui.

BW mengatur secara istimewa me-ngenai hubungan hukum tentang warisan antara ibu dan anak yang lahir di luar perkawinan yaitu termuat dalam Pasal $862-873$.

Pada dasarnya hak anak luar kawin yang diakui sah oleh bapak atau ibunya adalah tidak sama dengan anak sah. Hak anak luar kawin yang diakui sah diatur dalam Pasal $862 \mathrm{BW}$.

Bagian seorang anak yang lahir di luar perkawinan, tetapi diakui (erkend turlijk), itu tergantung dari berapa adanya anggota keluarga yang sah. Dengan ketentuan sebagai berikut:

1) Jika ada ahli waris dari golongan pertama, maka bagian anak yang lahir di luar perkawinan tersebut, $1 / 3$ (sepertiga) dari bagian yang akan diperolehnya seandainya ia dilahirkan dari perkawinan yang sah;

2) Jikalau tidak ada golongan pertama tetapi terdapat golongan ke-2 bersama-sama mewarisi, maka ia mewarisi 1/2 bagian yang akan diperolehnya seandainya ia dilahirkan dari perkawinan yang sah;

3) Jika hanya ada sanak keluarga yang lebih jauh dalam derajat keempat maka ia mewarisi 3/4 dari warisan (Pasal 863);

4) Kalau semua ahli waris tidak ada, maka ia mewarisi sepenuhnya harta warisan (Pasal 865).

Pembagian warisan, harus di-lakukan sedemikian rupa, sehingga bagian anak yang lahir diluar per-kawinan itu, harus dihitung dan dikeluarkan lebih dahulu, barulah sisanya dibagi antara ahli waris yang lainnya, seolah-olah sisa itu warisan yang masih utuh (Pasal 864).

\section{Contoh kasus:}


Jika ada 2 orang anak yang lahir di luar perkawinan menerima masingmasing $1 / 3 \times 1 / 5$, atau bersama-sama $2 / 15$. Bagian ini harus diambilkan lebih dahulu, dan sisanya $13 / 15$ dibagi antara anak-anak yang sah, yang karena masing-masing mendapat $13 / 30$ bagian dari warisan.

Terhadap anak yang lahir di luar perkawinan undang-undang juga memuat pasal-pasal perihal penggantian (plantsvervuling), sehingga apabila ia meninggal lebih dahulu ia dapat digantikan oleh anakanaknya sendiri. ${ }^{8}$

Dalam lingungan Hukum Perdata dibedakan antara anak luar kawin dengan anak zina. Anak zina dalam konsep hukum perdata adalah anak dari ayah dan ibu yang tak boleh kawin oleh karena sangat erat tali kekeluargaannya antara ayah dan ibu.

Anak zina menurut Pasal 867 sama sekali tidak mendapat harta warisan dari pewaris tetapi hanya berhak untuk men-dapatkan nafkah seperlunya. Dimana nafkah tersebut diatur menurut kekayaan ayah atau ibu dan juga keadaan ahli waris yang sah (Pasal 868).

Jika anak tersebut sudah men-dapatkan nafkah seperlunya waktu ayah atau ibu masih hidup maka ia tidak berhak menuntut lagi terhadap warisan ayah atau ibunya yang meninggal (Pasal 869).

\section{b. Hak Waris Bagi Anak Luar Kawin Menurut UU No. 1 tahun 1974}

UU No. 1 tahun 1974, anak yang terlahir dikarenakan hasil perzinahan tidaklah menjadi ahli waris dari harta ayahnya meskipun ibunya menikah saat mengandung anak itu.

Bersarkan beberapa pendapat ahli fikih tersebut, maka dapat disimpulkan bahwa anak luar kawin hanya mewarisi harta ibunya saja dan begitu sebaliknya ibunya mewarisi harta anak tersebut karena nasab anak tersebut disandarkan kepada ibunya bukan kepada laki-laki yang men-zinahi ibunya.

Ketentuan yang sama tertuang dalam Pasal 186 Inpres No. 1 tahun 1991 tentang KHI, bahwa anak luar kawin hanya mempunyai hubungan mewaris dengan ibunya dan keluarga dari pihak ibunya. Misalnya, yang meninggal [si pewaris] adalah bapak zinanya, maka si anak [laki-laki maupun perempuan] tidak memiliki hak untuk mewarisi. Tetapi apabila pewaris-nya adalah ibunya, maka ia berhak mewarisi.

Ketentuan yang sama juga berlaku bagi ibunya, bahwa ibu dapat mewarisi harta peninggalan anak luar kawinnya, jika anak tersebut meninggal dunia.

Tentang hak waris atas anak luar kawin yang lahir dari perkawinan campuran tunduk pada ketentuan warisan seperti juga harta peninggalan dari anak syah, hanya saja yang memiliki hak waris ialah ibunya sebesar

\footnotetext{
${ }^{8}$ Subekti, "Pokok-Pokok Hukum Perdata", (Jakarta: Internusa. 2002), hal. 100.
} 
1/3 dan selebihnya jatuh ke tangan perbendaharaan umum, kecuali dia me-ningalkan saudara-saudara seibu, maka golongan ini memperoleh $1 / 3$ pula. Jika golongan tersebut di atas tak ada maka seluruh harta peninggalan jatuh ke tangan Perbendaharaan Umum.

\section{Hak Waris Bagi Anak Luar Kawin Yang Lahir Dari Perkawinan Campur}

Pengaturan hak waris bagi anak luar kawin yang lahir dari perkawinan campur-an, jauh lebih pelik dari anak luar kawin yang lahir dari perkawinan bukan campuran. Permasalahan adalah bahwa terhadap anak luar kawin tersebut menyangkut dua sistem hukum yang berbeda hal ini berimplikasi pada pemilihan sistem hukum mana yang dipilih oleh mereka.

Sebagaimana telah dikemukakan dalam bagian terdahulu, bahwa status anak luar kawin yang lahir dari perkawinan campuran menurut UU Kewarganegaraan terbagi atas du kelompok, yaitu:

(1) anak luar nikah yang ibunya WNI dan ayahnya WNA;

(2) anak luar nikah yang ibunya WNA dan ayahnya WNI, tetapi sang ayah mau mengakui Anak tersebut sebagai Anaknya;

(3) anak luar nikah yang ibunya WNI lalu ayahnya WNA tapi sang ayah mau mengakui anak tersebut

Pada dasarnya untuk menentukan hukum waris mana yang berlaku atas diri seorang anak termasuk anak luar kawin berlaku hukum sebagai berikut: Pertama, bagi muslim maka berlaku Undang-Undang No. 1 Tahun 1974 tentang Perkawinan (UUP), Kompilasi Hukum Islam (KHI), dan Hukum Islam. Kedua, bagi non muslim berlaku Kitab Undang-Undang Hukum Perdata (KUHPerdata).

\section{Ad.1. Anak luar nikah yang ibunya WNI dan ayahnya WNA dan sebaliknya}

Berdasarkan ketentuan dalam Hukum Perdata, UU Perkawinan, KHI maupun Hukum Islam sepakat bahwa anak luar nikah yang tidak diakui oleh ayahnya, maka nasabnya hanya ada pada ibu dan keluarga ibunya. Artinya, bahwa anak tersebut hanya berhak mewarisi harta ibu dan keluarga ibunya.

Dengan demikian hak waris anak luar kawin yang lahir dari perkawinan campuran, hanya me-miliki hubungan hukum dengan ibu dan keluarga ibunya. Artinya, jika ibunya WNI muslim, maka padanya berlaku ketentuan yang ada pada UU Perkainan, KHI dan Hukum Islam. Sedangkan jika ibunya WNA, maka berlaku ketentuan hukum kewarga-negaraan Negara Ibunya.

Ad. 2. Anak luar nikah yang ibunya WNA dan ayahnya WNI, tetapi sang ayah mau mengakui Anak tersebut sebagai Anaknya dan sebaliknya 
Pengakuan anak luar nikah oleh ayah biologisnya, hanya berlaku dalam KUH Perdata dan tidak berlaku dalam UU Perkawinan dan KHI yang pada dasarnya mengadopsi sistem Hukum Islam terkecuali bagi anak li'an dan anak shubhat. Menurut ketentuan KUH Perdata, bahwa anak luar nikah yang diakui oleh ayah biologisnya, maka ia dianggap anak sah. Dengan demikian mereka me-miliki hak waris ayah sebagaimana anak-anak sah lainnya.

Menurut ketentuan KUH Perdata, bahwa anak luar nikah yang diakui oleh ayah biologisnya, maka ia dianggap anak sah. Dengan demikian mereka memiliki hak waris baik dari ayah maupun ibunya sebagaimana anak-anak sah lainnya. Hal ini berbeda dengan UU No. 1 tahun 1974, dalam UU No. 1 tahun 1974 tidak dikenal pengakuan terhadap anak luar nikah. Artinya, meskipun ayah dari si anak mengakui bahwa anak tersebut adalah anaknya, tetapi ia terlahir dari hubungan di luar nikah maka ia tetap dianggap sebagai anak luar kawin dan tidak memiliki hak waris dari ayah biologisnya.

\section{Penutup}

Anak-anak yang lahir dari hubungan luar kawin lalu diakui atau diakui secara sah oleh ayahnya yang WNA atau WNI, seperti tersebut diatas, dan ia belum berusia 18 (delapan belas) tahun atau belum kawin memperoleh Kewarganegaraan Republik Indonesia berdasarkan Undang-Undang 12/2006 dengan mendaftarkan diri kepada Menteri melalui Pejabat atau Perwakilan Republik Indonesia paling lambat 4 (empat) tahun setelah Undang-Undang ini diundangkan.

Menurut KUH Perdata, anak luar kawin yang lahir dari perkawinan campuran, hanya memiliki hubungan hukum dengan ibu dan keluiarga ibunya, terkecuali diakui oleh ayah biologisnya. Artinya bahwa anak luar kawin yang lahir dari perkawinan campuran yang diakui oleh ayah biologisnya memiliki hak waris baik dari ayah maupun ibunya. Meski demikian, hak waris anak luar kawin yang diakui sah oleh bapak atau ibunya adalah tidak sama dengan anak sah.

Menurut UU No. 1 tahun 1974 yang pada dasarnya mengadopsi Hukum Islam, bahwa anak di luar kawin tidak dapat diakui maupun dipisahkan oleh bapaknya (bapak alamnya). Anak-anak tersebut hanya mempunyai hubungan hukum dengan ibunya tetapi si anak tetap mempunyai ibu yang melahirkannya, dengan pengertian bahwa antara anak dan ibu itu ada hubungan hukum dan sama seperti halnya dengan anak sah yang mempunyai bapak. Hakikat hukum Islam tersebut anak di luar kawin termasuk anak tidak sah. Meskipun orang tuanya telah melakukan pengakuan atau pengesahan tapi karena akibat anak itu lahir di luar perkawinan orang tuanya tetap saja pandangan masyarakat bahwa anak tersebut tidak sah.

Anak yang lahir di luar perkawinan atau sebagai akibat hubungan suami isteri yang tidak sah, hanya mempunyai hubungan nasab, hak dan kewajiban nafkah serta hak dan hubungan kewarisan dengan ibunya serta keluarga ibunya 
saja, tidak dengan ayah/bapak alami (genetiknya), begitu juga ayah/bapak alami (genetik) tidak sah menjadi wali untuk menikahkan anak alami (genetiknya), jika anak tersebut kebetulan anak perempuan. 


\section{Daftar Pustaka}

Abdurrahman. Kompilasi Hukum Islam, Jakarta: Akademika Presindo, 1995.

Afandi, Ali. Hukum Waris, Hukum Keluarga, Hukum Pembuktian menurut KUHP (BW), Jakarta: Bina Aksara, 1984.

al-Asqalani, Ibn Hajar. Fath al-Barry, Juz XII, Beirut: Dar al-Fikr, th.

al-Mahalli, Jalaluddin. al-Qulyuby wa 'Umarah', Juz III, Semarang: Maktabah Putra Semarang, t.th.

al-Qadhawi, Yusuf. Halal dan Haram dalam Islam, Surabaya: Bina Ilmu, 1976.

Al-Syathibi. al-Muwafaqat fi Ushul al-Syari'ah, Juz II, Beirut: Dar al-Kutub al-Islamiyah, t.th.

al-Zuhailiy, Wahbah. Al-Fiqh al- Islamiy wa Adillatuhu, Beirut: Dar al-Fikr, 1997.

Hartono, Surjopratiknjo. Hukum Waris Tanpa Wasiat, Sie Notariat. Yogyakarta: Fak. Hukum UGM, 1982.

Hasan, Djuhaedah. Hukum Keluarga Setelah Berlakunya Undang-Undang Nomor 1 Tahun 1974, Bandung: Armico, 1988.

Hasan, M. Ali. Azas-azas Hukum Islam: Pengantar Ilmu Hukum dan Tata Hukun Islam di Indonesia, Jakarta: Rajawali Press, 1997.

Kapojos, I.C.R-M. Diktat Hukum Waris, Manado: Fak. Hukum UNSRAT, 1997.

Mahdi, Sri Susilowati., Sjarif, Surini Ahlan dan Cahyono, Akhmad Budi. Hukum Perdata; Suatu Pengantar, Jakarta: Gitama Jaya Jakarta, 2005.

Manan, Abdul. Aneka Masalah Hukum Perdata Islam di Indonesia, Jakarta: Kencana, 2008.

Muslim, Imam. Shahih Muslim, Beirut: Dar al-Fikr, t.th.

Nelli, Jumni. "Nasab-Anak-Luar-Nikah-Perspektif-Hukum-Islam-DanHukum”, <http://www.docstoc.com/docs/20488457/Nasab-Anak-LuarNikah-Perspektif-Hukum-Islam-Dan-Hukum>, diakses 12 Desember 2007.

Oemarsalim. Dasar-Dasar Hukum Waris di Indonesia, Jakarta: Rineka Cipta, 1991.

Pitlo, A. Hukum Waris Menurut KUHPerdata, Jakarta: Intermasa, 1979.

Prodjodikoro, Wirjono. Hukum Warisan di Indonesia. Bandung: Sumur, 1974.

Rusyd, Ibnu. Bidayah al-Mujtahid, Juz V. Beirut: Dar al- Fikr, t.th.

Sholeh, KHO., Dahlan, HAA., Dahlan, MD. Asbabun Nuzul, Bandung: Diponegoro, t.th.

Subekti. Pokok-Pokok Hukum Perdata, Jakarta: Internusa, 2002.

Syarifuddin, Amir. Meretas Kebekuan Ijtihad, Jakarta: Ciputat Press, 2002. 
Tamakiran. Asas-Asas Hukum Waris Menurut Tiga Sistem Hukum, Jakarta: Pioneer Jaya, 1987.

Vollmar, H.F.A. Pengantar Studi Hukum Perdata, Penterjemah I. S. Adiwimarta. Jakarta: Rajawali, 1997. 